OPEN ACCESS

Edited by:

Shu Jiang,

The University of Utah, United States

Reviewed by:

Tao Hu,

China University of Petroleum, China

Xianglu Tang,

China University of Petroleum, China

Yishu,

Jianghan Oilfield Branch Company,

China

*Correspondence:

Lei Chen

cl211@126.com

Specialty section:

This article was submitted to

Economic Geology,

a section of the journal

Frontiers in Earth Science

Received: 04 January 2022 Accepted: 11 February 2022

Published: 01 March 2022

Citation:

Chen X, Chen L, Tan X, Wang C, Ji Y, Xiong $M$ and Wang $G$ (2022) Pore Characterization of Pyrite in the Longmaxi Formation Shale in the Upper Yangtze Area of China. Front. Earth Sci. 10:848247. doi: 10.3389/feart.2022.848247

\section{Pore Characterization of Pyrite in the Longmaxi Formation Shale in the Upper Yangtze Area of China}

\author{
Xin Chen ${ }^{1,2}$, Lei Chen ${ }^{1,2 *}$, Xiucheng Tan ${ }^{1,2,3}$, Chao Wang ${ }^{4}$, Yubing $\mathrm{Ji}^{5}$, Min Xiong ${ }^{1,2}$ and \\ Gaoxiang Wang ${ }^{1,6}$
}

${ }^{1}$ School of Geoscience and Technology, Southwest Petroleum University, Chengdu, China, ${ }^{2}$ Sichuan Natural Gas Geology Key Laboratory Southwest Petroleum University, Chengdu, China, ${ }^{3}$ State Key Laboratory of Oil and Gas Reservoir Geology and Exploitation, Southwest Petroleum University, Chengdu, China, ${ }^{4}$ Exploration and Development Research Institute, SINOPEC Jianghan Oil Field Company, Wuhan, China, ${ }^{5}$ Zhejiang Oilfield Company, PetroChina, Hangzhou, China, ${ }^{6}$ Research Institute of Shale Gas, Southwest Oil and Gas Field Company, PetroChina, Chengdu, China

Pyrite is widely distributed in the Longmaxi marine shale in the Upper Yangtze area of China. Pyrite, one of the important components of shale, has an important influence on the enrichment of shale gas. However, there are currently only a few studies on this topic. Based on shale samples from drilling cores using field emission scanning electron microscopy, the pore characteristics of pyrite from the Longmaxi Formation in the Upper Yangtze area of China are studied. The results showed that the intergranular pores of pyrite and abundant organic pores in the organic matter pyrite assemblages are developed in the Longmaxi Formation shale in the study area. Most pyrite framboid pores have triangular or irregular quadrilateral shapes, with pore diameters ranging from 0 to $240 \mathrm{~nm}$. Pores with diameters of $80-240 \mathrm{~nm}$ are the major reservoir spaces for shale gas within the pyrite framboids. The average contribution rate of pyrite framboids to shale pores reaches $3.21 \%$, and the highest contribution is $5.66 \%$, indicating that the pyrite pores may have a favorable contribution to the shale reservoir pore system, but the contribution degree is low.

Keywords: pore, pyrite, shale, Longmaxi formation, Upper Yangtze area

\section{INTRODUCTION}

In recent years, the exploration and development of shale gas have achieved a great success in North America and the Sichuan Basin in China (Hao et al., 2013; Chen et al., 2015; Zou et al., 2016; Chen et al., 2019; Shu et al., 2020), which has attracted worldwide attention. Nanopores in shale reservoirs are well developed in diverse types and structures, effectively providing storage space for shale gas. The structural characteristics of nanopores are important and difficult aspects of the theoretical study of shale gas geology (Ross and Bustin, 2008a; Clarkson et al., 2013). Pore characteristics are important determinants of the gas content in shale gas reservoirs and are the keys to shale reservoir evaluation. Therefore, studying the pore characteristics of reservoirs is of great significance for shale gas exploration, development, and resource potential evaluation (Loucks et al., 2009; Roger and Neal, 2011; Gao et al., 2019).

Scholars have performed many studies on the pore characteristics and structure of marine shale, including different types of pores, pore structures, and connectivity of shale gas reservoirs on different scales (Loucks et al., 2009; Kuila and Prasad, 2013; Zargari et al., 2015; Jiang et al., 2016; 


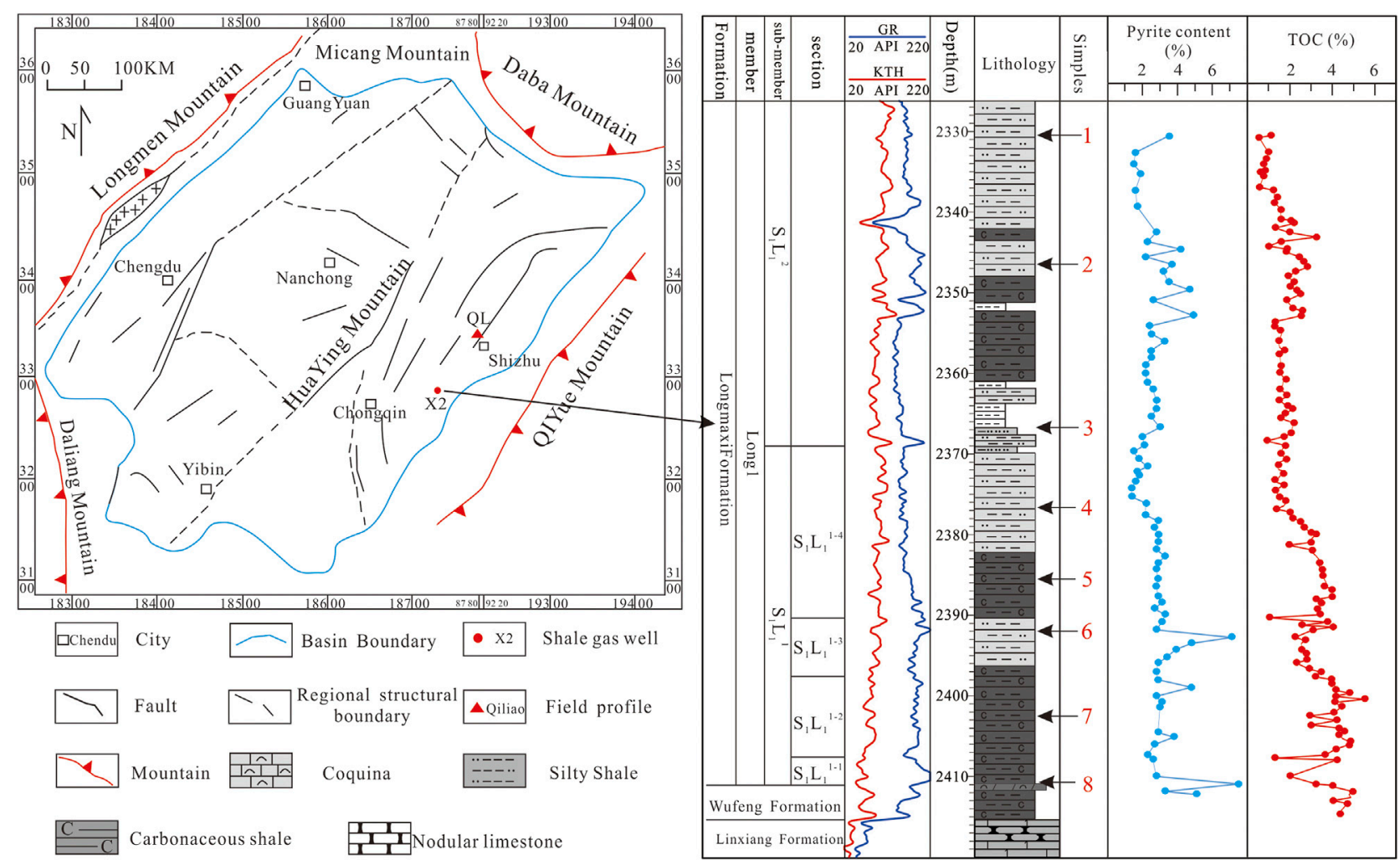

FIGURE 1 | Location of the study area and stratigraphic column of the Longmaxi Formation and the gamma-ray log of the X2 well (Wang et al., 2002).

Zheng et al., 2019). Presently, the research contents on shale pore structure mainly focused on 1) shale pore classification (IUPAC, 1994; Slatt and O’Brien, 2011; Ruppel et al., 2012; Yu, 2013), 2) microstructural characteristics of shale pores (Loucks et al., 2009; Ross and Bustin, 2008b; Jiang et al., 2016), 3) formation mechanisms of shale pores and factors influencing pore development (Jarvie et al., 2007; Chalmers and Bustin, 2008; Zhang et al., 2016; Zheng et al., 2019), and 4) shale pore evolution (Chen and Xiao, 2014; Lu et al., 2015; Zargari et al., 2015; Tang et al., 2015). The results have shown that the organic matter type, maturity, and mineral composition are closely related to the pore structure (Kuila and Prasad, 2013; Duan et al., 2016; Wei et al., 2016). With increasing thermal evolution level, organic matter transforms to hydrocarbons, and nanopores are widely developed in organic-rich shale, thereby providing abundant storage space for shale gas. The major types of pores and fractures in shale reservoirs are organic pores, intragranular pores, intergranular pores, and microfractures. Nanopores mainly provide connected storage space for shale gas (Ruppel et al., 2012; Yu, 2013).

Current research studies on pyrite in shale mainly focuses on the following aspects: 1) the correlation between pyrite and the shale sedimentary environment (Wilkin et al., 1996; Raiswell et al., 1988; Butler and Rickard, 2000; Liu et al., 2019), and 2) the organic matter content is proportional to the pyrite content (Xu et al., 2015; Liu et al., 2016). Many scholars have found that pores related to pyrite in marine shale are universally developed (Bernard et al., 2012; Wang Q. et al.,
TABLE 1 | Information of shale samples in well X2.

\begin{tabular}{lccccc} 
Number & Well & Stratum & Depth/m & Lithology & Test items \\
\hline 1 & X2 & $\mathrm{S}_{1} 1$ & 2330.46 & Shale & FE-SEM \\
2 & & & 2346.50 & & \\
3 & & & 2366.74 & & \\
4 & & & 2376.05 & & \\
5 & & & 2385.42 & & \\
6 & & & 2391.95 & & \\
7 & & & 2402.55 & & \\
8 & & & 2411.05 & &
\end{tabular}

2014; Cao et al., 2018; Zhao et al., 2018; Tang et al., 2019). Although shale pores are fully studied, there are few reports on pores related to pyrite in shale. To determine the development characteristics of pyrite pores, especially pores within the pyrite framboids and their geological significance, pyrite pores in the marine shale of the Longmaxi Formation in the Upper Yangtze area were studied in this research.

\section{GEOLOGICAL SETTING}

Organic-rich shale (TOC>2\%) is well developed in the Wufeng Formation and the first member of the Longmaxi Formation in the Upper Yangtze area, and kerogen is mainly composed of sapropel (Types $\mathrm{I}-\mathrm{II}_{1}$ ). The organic-rich shale is widely distributed in the Upper Yangtze area, with burial depths 


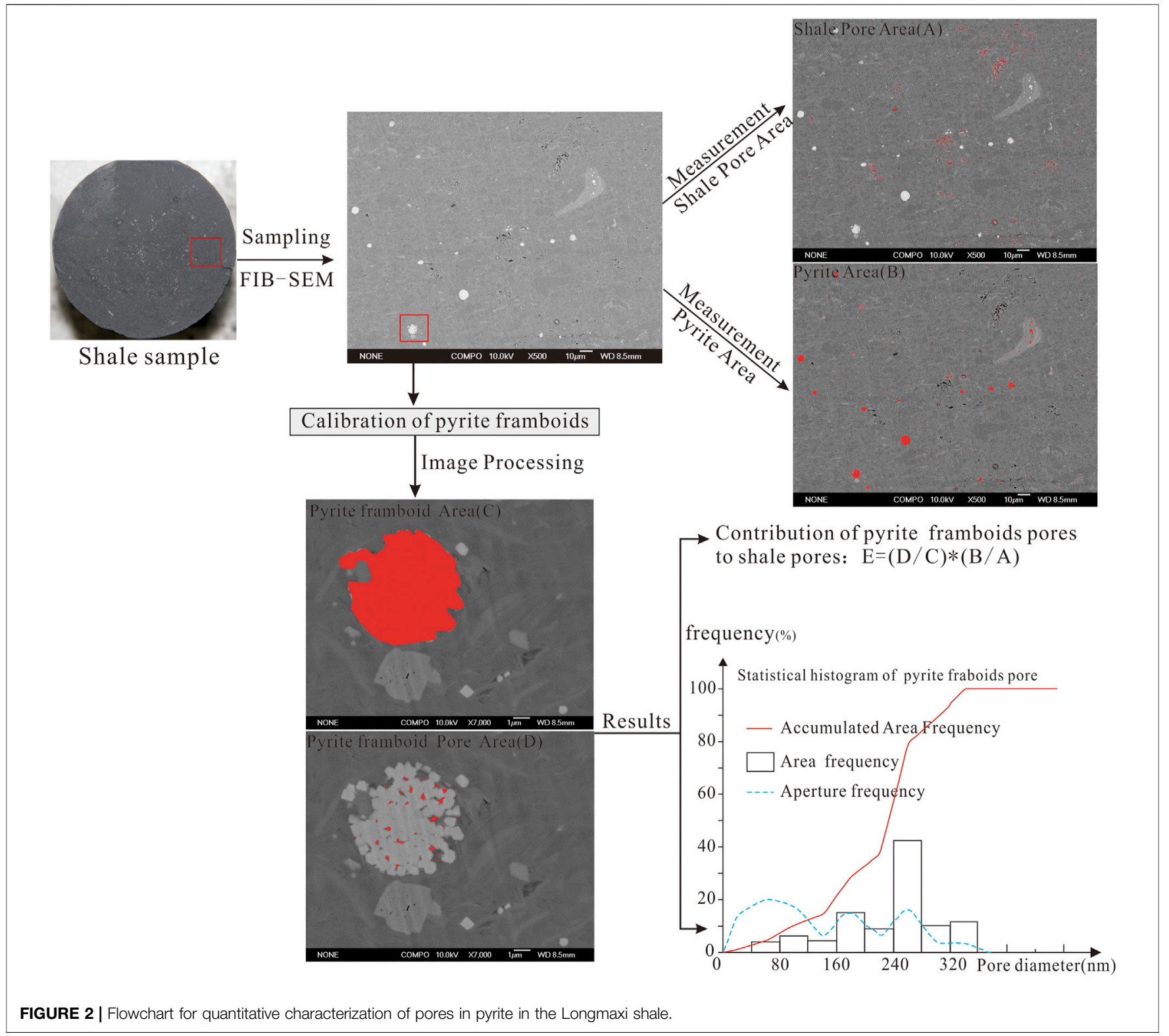

ranging from $1,500 \mathrm{~m}$ to $4,500 \mathrm{~m}$. The Longmaxi marine shale is characterized by large thicknesses $(20-50 \mathrm{~m})$, high TOC, and high maturity, and is one of the most favorable shale gas exploration targets in China (Zou et al., 2014; Guo, 2015; Tenger et al., 2017; Shan et al., 2017).

Previous studies have shown that the high-quality shale section of the Longmaxi Formation is mainly in $S_{1} 1_{1}$, which can be divided into two sub sections. $S_{1} l_{1}{ }^{1}$ is the most favorable interval for the exploration and development of high-quality shale in the Longmaxi Formation (Zou et al., 2016). $\mathrm{S}_{1} \mathrm{l}_{1}{ }^{1}$ can be divided into 4 sub-layers (Zhao et al., 2016). The study area is mainly in the Upper Yangtze region. Taking well X2 as an example, $S_{1} 1_{1}{ }^{1}$ mainly contains gray-black and black silty shale with a thickness of approximately $36 \mathrm{~m}$ (Figure 1).

$\mathrm{S}_{1} \mathrm{l}_{1}{ }^{1-1}$ contains black silty shale with a thickness of approximately $1.2 \mathrm{~m}$, the TOC contents are within $3-6 \%$, and the pyrite contents are within 2-8\%. $\mathrm{S}_{1} \mathrm{l}_{1}{ }^{1-2}$ comprises gray-black silty shale and carbonaceous shale with a thickness of approximately $9.5 \mathrm{~m}$. The TOC contents are within $3-4 \%$, and the pyrite contents are within $2-6 \%$. $\mathrm{S}_{1} \mathrm{l}_{1}{ }^{1-3}$ contains gray-black carbonaceous shale and silty shale, is approximately $8.5 \mathrm{~m}$ thick, and has TOC contents within $2-4 \%$ and pyrite contents within $2-8 \% . \quad \mathrm{S}_{1} \mathrm{l}_{1}{ }^{1-4}$ comprises gray-black shale and silty shale, has a thickness of approximately $23.2 \mathrm{~m}$, and low TOC contents of $1.5-2.5 \%$ and pyrite contents of $1-4 \%$ (Figure 1).

\section{MATERIALS AND METHODS}

To characterize the pores related to pyrite in the Longmaxi Formation shale in the Upper Yangtze area, eight shale samples 


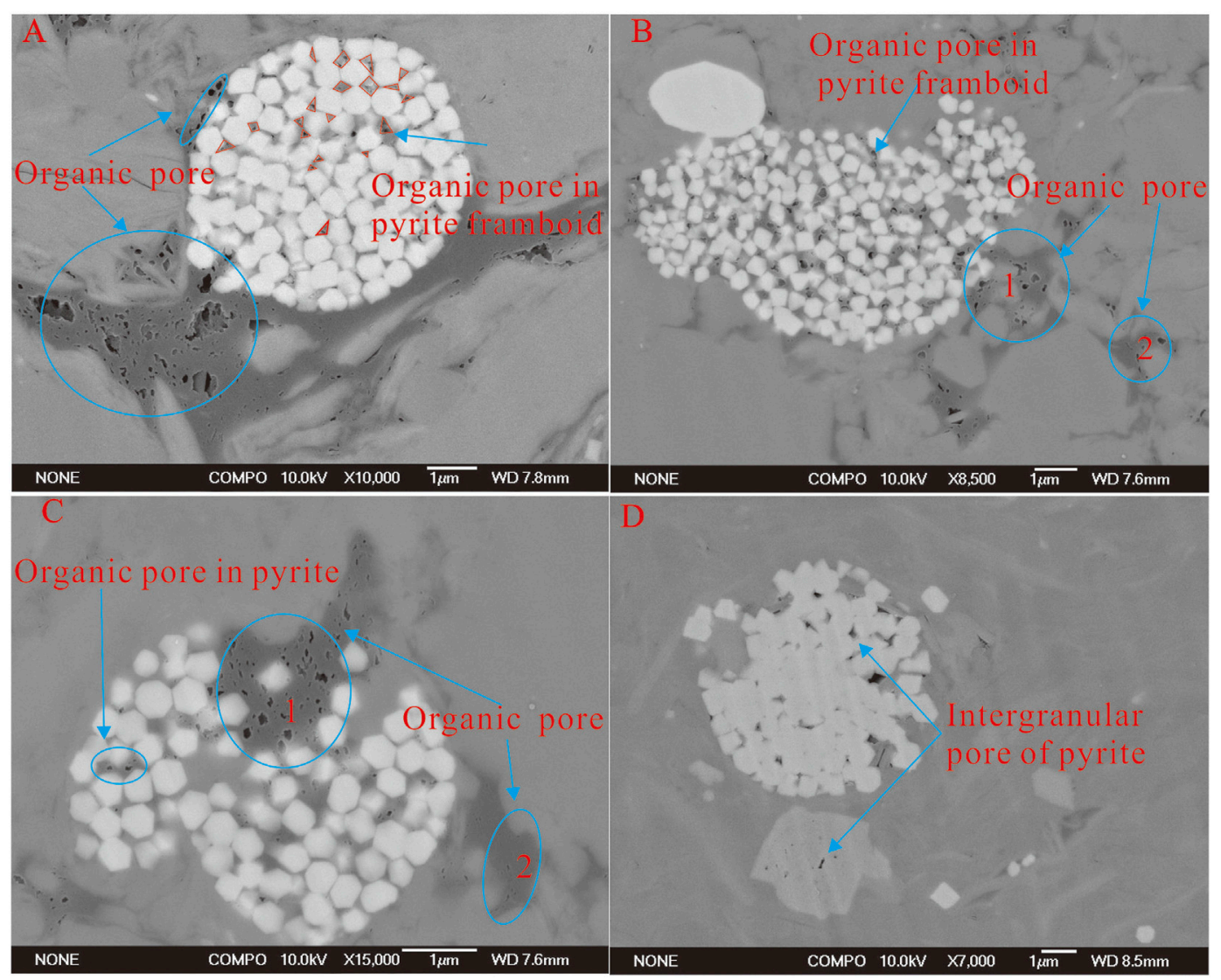

FIGURE 3 | Common pore types associated with pyrite in the Longmaxi Formation shale in the southeastern basin. (A) Organic pore in pyrite framboid, X2 well, 2376.05 m; (B) organic pore in pyrite framboid, X2 well, 2385.42 m; (C) organic pore in pyrite framboid, X2 well, 2385.42 m; (D) intergranular pore of pyrite, X2 well, $2335.30 \mathrm{~m}$

TABLE 2 | Pore development characteristics of pyrite framboids.

\begin{tabular}{|c|c|c|c|c|}
\hline Sample & Depth/m & Pore diameter/nm & Pore diameter frequency $/ \%$ & Area frequency $/ \%$ \\
\hline \multirow[t]{3}{*}{1} & 2330.46 & $<80$ nm & 72.12 & 5.41 \\
\hline & & $80-240 \mathrm{~nm}$ & 22.96 & 47.68 \\
\hline & & $>240$ nm & 4.92 & 46.91 \\
\hline \multirow[t]{3}{*}{2} & 2346.50 & $<80 \mathrm{~nm}$ & 61.94 & 22.19 \\
\hline & & $80-240 \mathrm{~nm}$ & 37.17 & 71.64 \\
\hline & & $>240$ nm & 0.88 & 6.19 \\
\hline \multirow[t]{2}{*}{3} & 2366.74 & $<80 \mathrm{~nm}$ & 90.91 & 58.44 \\
\hline & & $80-240$ nm & 9.09 & 41.56 \\
\hline \multirow[t]{3}{*}{5} & 2385.42 & $<80 \mathrm{~nm}$ & 51.97 & 13.95 \\
\hline & & $80-240 \mathrm{~nm}$ & 45.1 & 76.96 \\
\hline & & $>240$ nm & 1.62 & 9.09 \\
\hline \multirow[t]{3}{*}{7} & 2402.55 & $<80$ nm & 72.84 & 14.89 \\
\hline & & $80-240 \mathrm{~nm}$ & 22.22 & 44.06 \\
\hline & & $>240 \mathrm{~nm}$ & 4.93 & 41.04 \\
\hline
\end{tabular}

from drilling cores of well X2 drill cores were used in this study for argon ion polishing field emission scanning electron microscopy (FE-SEM) analysis and quantitative characterization experiments of pores in pyrite (Table 1).

\section{FE-SEM}

Core samples were cut into standard samples of $1 \mathrm{~cm} \times 1 \mathrm{~cm}$. Then, an IB-09010CP ion section polishing instrument was used for argon ion polishing processing on the surfaces of the samples. 

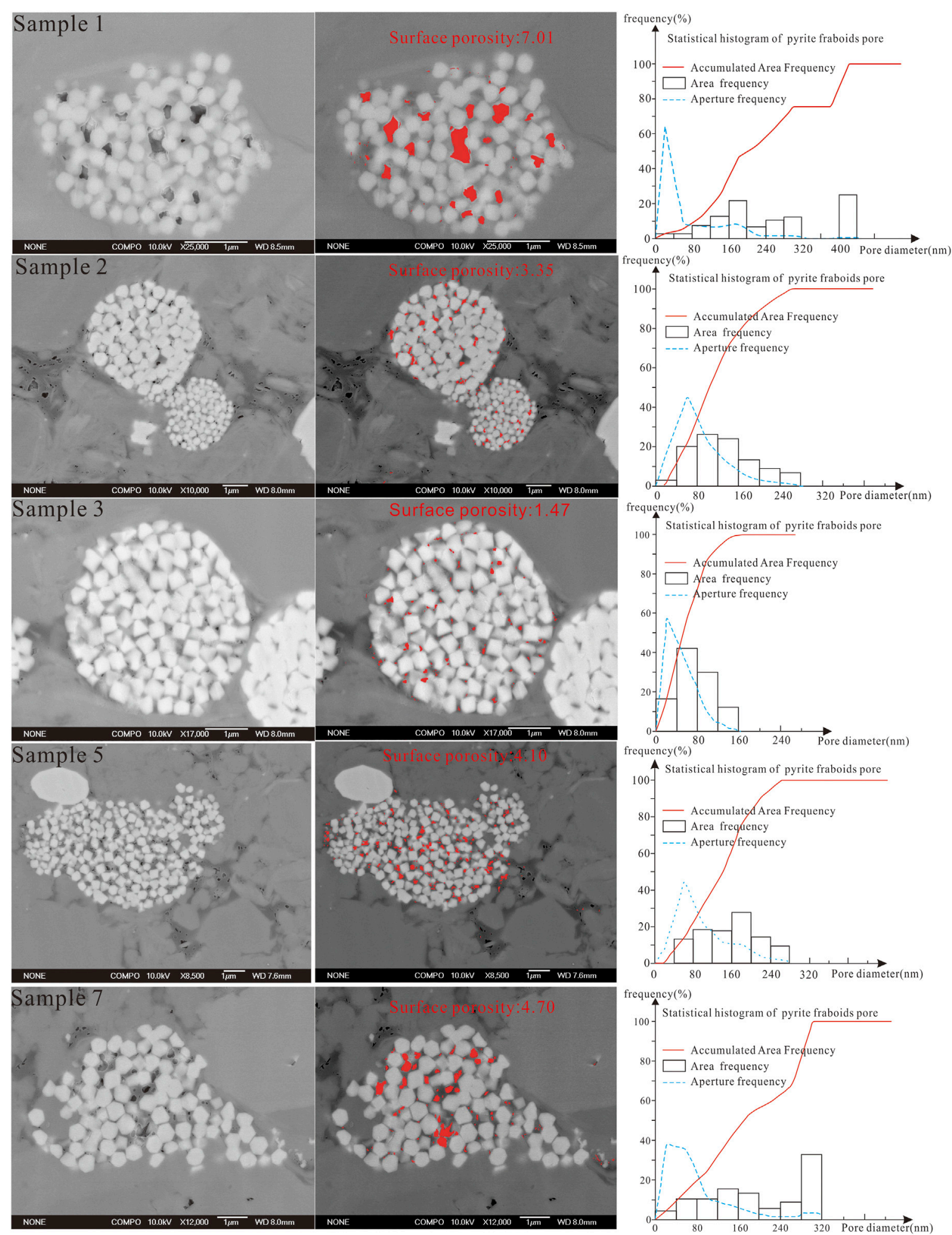

FIGURE 4 | Quantitative characterization of pores in pyrite framboids of shale samples from X2 well. 1, Black shale, X2 well, 2330.46 m; 2 , black shale, X2 well, 2335.30 m; 3, black shale, X2 well, 2346.50 m; 5, black shale, X2 well, 2366.74 m; 7, black shale, X2 well, 2402.55 m. 
TABLE 3 | Quantitative statistical results of pores in pyrite framboids of shale samples from X2 well.

\begin{tabular}{|c|c|c|c|c|c|}
\hline Sample & Depth/m & $\begin{array}{c}\text { Average area } \\
\text { ratio of } \\
\text { pyrite/ } \%\end{array}$ & $\begin{array}{c}\text { Pyrite framboids } \\
\text { average face } \\
\text { rate } / \%\end{array}$ & $\begin{array}{c}\text { Sample average } \\
\text { face rate } / \%\end{array}$ & $\begin{array}{c}\text { Pore contribution } \\
\text { rate/\% }\end{array}$ \\
\hline 1 & 2330.46 & 0.95 & 5.37 & 1.97 & 2.59 \\
\hline 2 & 2346.50 & 2.20 & 3.72 & 2.46 & 3.33 \\
\hline 3 & 2366.74 & 1.33 & 1.47 & 1.8 & 1.09 \\
\hline 4 & 2376.05 & 1.3 & 3.63 & 1.34 & 3.52 \\
\hline 5 & 2385.42 & 1.5 & 4.10 & 1.68 & 3.66 \\
\hline 6 & 2391.95 & 2.34 & 6.43 & 2.66 & 5.66 \\
\hline 7 & 2402.55 & 1.28 & 4.7 & 2.86 & 2.10 \\
\hline 8 & 2411.05 & 1.8 & 4.63 & 2.23 & 3.74 \\
\hline
\end{tabular}

A JSM-6700F cold field emission scanning electron microscope was used for image collection at a $10 \mathrm{KV}$ acceleration voltage and $10 \mu \mathrm{A}$ beam current.

\section{Pyrite Content}

First, the shale rock sample was dried and crushed into a powder with a grain size less than $40 \mu \mathrm{m}$, and finally made into a test piece for later use. Each type of mineral crystal has a specific X-ray diffraction spectrum through which qualitative and quantitative results can be obtained because the characteristic peak strength in the spectrum is related to the mineral content of the sample. The XRD test was accomplished by using the Panalytical X'Pert PRO MPD X-ray diffractometer.

\section{Quantitative Characterization of Pyrite Pores}

To quantitatively study the contribution of pores within the pyrite framboids to the total porosity of the shale reservoir, the following technical methods were applied: 1) FE-SEM (scanning electron microscope) was used to obtain microscopic images of shale, and the shale images were magnified to the $\mu \mathrm{m}$-nm scale to observe the pyrite framboids; 2) image analysis software was used for image gray level segmentation to calculate the area of pyrite and shale pores; 3) pyrite framboids were demarcated, multiple individual pyrite framboids were selected to calculate the development area of pyrite framboids, and the pore area and aperture of developed pores in the microscopic area were ascertained to calculate the average face rate of pore development in pyrite framboids; and 4) the approximate contributions of pyrite framboids to the total porosity of shale were quantitatively represented by multiplying the area percentage of pyrite area in the microscopic image by the average face rate of pyrite framboids and by dividing by the total face rate of shale in the microscopic image (Figure 2).

\section{RESULTS AND DISCUSSION}

\section{Pore Types in Pyrite in Shale}

The common pore types in pyrite in the Longmaxi Formation shale in the Upper Yangtze area are as follows: abundant organic pores are developed in the organic matter pyrite assemblages; these pores are the most common type of pores that are closely related to pyrite in the Longmaxi Formation shale (Figure 3). A small number of irregular intercrystalline pores are found within the pyrite framboids, appearing as monomers, composed of pyrite microcrystalline groups but not filled by organic matter (Figure 3D). Intergranular and organic pores in pyrite can provide space for the preservation of shale gas.

According to FE-SEM analysis, the organic pores related to pyrite (Figure 3, B1, C1) are much more numerous and larger than individual organic pores that are developed far away from the pyrite (Figure 3, B2, C2), which means that pyrite may influence hydrocarbon generation and expulsion of organic matter and pore development. Organic pores in the organic matter pyrite assemblages mainly occur for the following two reasons: 1) The organic pores in pyrite as shown in Figure $\mathbf{3 A}$ are supported and protected by the stable triangular stress lattice generated between pyrite microcrystalline grains from later diagenesis (compaction) (Sun and Guo, 2017; Zhao et al., 2018). 2) Pyrite can catalyze the hydrocarbon generation of organic matter, which promotes the development of more organic pores in organic matter around pyrite (Hunt et al., 1991; Mango, 1992; Cui et al., 2013; Wang Y. M. et al., 2014; Cai et al., 2016; Ma et al., 2017).

\section{Characteristics of Nanopores in Pyrite}

Pyrite occurs mainly in the form of pyrite framboids in shale. Nanopores (intergranular pores and organic pores in pyrite framboids) are one of the basic reservoir pore types in shale (Loucks et al., 2009; Yu, 2013; Curtis et al., 2012; Guo et al., 2014) and play an important role in the shale reservoir pore system $(\mathrm{Hu}$ et al., 2015; Cao et al., 2018).

According to the FE-SEM analysis of the shale samples from well X2, the pore characteristics of pyrite framboids in shale are studied. According to the research, the organic pores of pyrite framboids in sample 1 are well developed and have a face rate reaching $7.01 \%$. The pore diameter is relatively dispersive and is mainly divided into two categories: pores with a diameter of $<80 \mathrm{~nm}$ account for $72.12 \%$, with an area frequency of $5.41 \%$, and pores with a diameter of $80-240 \mathrm{~nm}$ account for $22.96 \%$, with an area frequency of $47.68 \%$. In sample 2 , the pore diameters of pyrite framboids are relatively dispersed and are within $0-280 \mathrm{~nm}$, with a face rate of $3.35 \%$; these pore diameters are mainly divided into two categories: pores with a diameter of $<80 \mathrm{~nm}$ account for $61.94 \%$, with an area frequency of $22.19 \%$, and pores with a diameter of $80-240 \mathrm{~nm}$ account for $37.17 \%$, with 
an area frequency of $71.64 \%$. In sample 3, pyrite framboids are well crystallized in an ellipsoidal shape, with the face rate reaching $1.47 \%$. The pore diameters of pyrite framboids are relatively small overall and are $<80 \mathrm{~nm}$, with an area frequency of $58.44 \%$. In sample 5 , pyrite framboids show relatively inferior crystallization, with a face rate of $4.10 \%$. The pore diameters are concentrated within $<80 \mathrm{~nm}$ and from 80 to $240 \mathrm{~nm}$ overall, with pore diameter frequencies of 51.97 and $45.1 \%$ and area frequencies of 13.95 and $76.96 \%$. In sample 7 , organic pores are well developed within the dispersive microcrystalline pyrite with a face rate reaching $4.70 \%$. The pores are mainly divided into two categories: pores with a diameter of $<80 \mathrm{~nm}$ account for $72.84 \%$, with an area frequency of $14.89 \%$ and pores with a diameter of $40-100 \mathrm{~nm}$ account for $22.22 \%$, with an area frequency of $44.06 \%$ (Table 2; Figure 4).

Overall, pores in pyrite framboids mostly occur in triangular and trapezoidal shapes, with diameters universally smaller than $320 \mathrm{~nm}$. The diameters of pores in pyrite framboids are $0-240 \mathrm{~nm}$, mostly within $0-120 \mathrm{~nm}$. More than $95 \%$ of the pores are smaller than $240 \mathrm{~nm}$. Although most pores in pyrite framboids are in the range of $0-80 \mathrm{~nm}$, their pore area ratios are relatively low, generally lower than $15 \%$. Their contributions to pyrite pores are also low. The pores in pyrite framboids with diameters of $80-240 \mathrm{~nm}$, which account for $40-75 \%$ of the pore area, are the primary storage spaces for shale gas in the pyrite framboids. Pores larger than $240 \mathrm{~nm}$ are less than 5\%. In general, the larger the pore is, the larger the face rate will be and the better the storage property of pyrite will be.

\section{Contributions of Nanopores in Pyrite to Shale Reservoir Pores}

Taking multiple photographs (greater than or equal to 200 for every sample) of 8 shale samples in different visual fields by using FE-SEM and then calculating observation statistics on the pores in the pyrite framboids, the results showed that intracrystalline and organic pores are developed in pyrite framboid aggregates, with organic pores prevailing. For pyrite framboid aggregates (containing pyrite microcrystals) in shale, the area ratio values are $0.95-2.34 \%$, with an average of $1.59 \%$, and the face rate values are $1.47-6.43 \%$, with an average of $4.26 \%$. In addition, the face rate values of all pores in shale are $1.34-2.86 \%$, with an average of $2.13 \%$. The contribution of pores in pyrite to the pores in shale is $1.09-5.66 \%$, with an average of $3.21 \%$. These pores can not only increase the shale reservoir space and specific surface area of shale but also reserve free gas and promote the enrichment of shale gas in the Longmaxi Formation. It is shown that the pores in pyrite in shale have favorable contributions to the shale reservoir pore system (Table 3).

\section{REFERENCES}

Bernard, S., Horsfield, B., Schulz, H.-M., Wirth, R., Schreiber, A., and Sherwood, N. (2012). Geochemical Evolution of Organic-Rich Shales with Increasing Maturity: A STXM and TEM Study of the Posidonia Shale (Lower Toarcian, Northern Germany). Mar. Pet. Geology. 31 (1), 70-89. doi:10.1016/j.marpetgeo.2011.05.010

\section{CONCLUSION}

The intergranular pores in pyrite and abundant organic pores in the organic matter pyrite assemblages are well developed in the Longmaxi Formation shale in the Upper Yangtze area of China. Pyrite framboids are the major forms of pyrite in shale, and most pyrite framboids pores occur in triangular or irregular quadrilateral shapes, with pore diameters mainly between 0 and $240 \mathrm{~nm}$. Pores with diameters of $80-240 \mathrm{~nm}$ are the major reservoir spaces for shale gas in the pyrite framboids. For pyrite framboid aggregates (containing pyrite microcrystals) in shale, the face rate values are $1.47-6.43 \%$, with an average of $4.26 \%$, and its contributions to the pores in shale are $1.09-5.66 \%$, with an average of $3.21 \%$, which indicates that pyrite pores in shale may be favorable to the shale reservoir pore system. These pores can not only increase the shale reservoir space and specific surface area of shale but also reserve free gas and promote the enrichment of shale gas in the Longmaxi Formation.

\section{DATA AVAILABILITY STATEMENT}

The raw data supporting the conclusions of this article will be made available by the authors, without undue reservation.

\section{AUTHOR CONTRIBUTIONS}

$\mathrm{XC}$ was the major author of the article. MX and LC conceived the project. XT collected the samples. GW analyzed the samples. All authors contributed to the article and approved the submitted version.

\section{FUNDING}

This study was jointly funded by the National Natural Science Foundation of China (Grant No. 41602147) and Science and Technology Cooperation Project of the CNPC-SWPU Innovation Alliance (Grant No. 2020CX020000).

\section{ACKNOWLEDGMENTS}

We are grateful to the Guest Associate Editor Kun Zhang and three reviewers for their insightful and constructive comments both in science and English, which have substantially improved the article.

Butler, I. B., and Rickard, D. (2000). Framboidal Pyrite Formation via the Oxidation of Iron (II) Monosulfide by Hydrogen Sulphide. Geochimica et Cosmochimica Acta 64 (15), 2665-2672. doi:10.1016/s0016-7037(00)00387-2

Cai, X., Wang, L., Jin, Y. X., Gao, Y. Q., Cao, H. H., and Ding, A. X. (2016). Types and Characteristics of Organic Pore in Shale Gas Reservoir of southeastern Chongqing Area. Nat. Gas Geosci. 27 (3), 513-519. doi:10.11764/j.issn.16721926.2016.03.0513 
Cao, T. T., Deng, M., Song, Z. G., Liu, G. X., Huang, Y. R., and Hursthouse, A. S. (2018). Study on the Effect of Pyrite on the Accumulation of Shale Oil and Gas. Nat. Gas Geosci. 29 (03), 404-414. doi:10.11764/j.issn.1672-1926.2017.12.006

Chalmers, G. R. L., and Bustin, R. M. (2008). Lower Cretaceous Gas Shales in Northeastern British Columbia, Part I: Geological Controls on Methane Sorption Capacity. Bull. Can. Pet. Geology. 56 (1), 1-21. doi:10.2113/ gscpgbull.56.1.1

Chen, J., and Xiao, X. (2014). Evolution of Nanoporosity in Organic-Rich Shales during Thermal Maturation. Fuel 129, 173-181. doi:10.1016/j.fuel.2014.03.058

Chen, L., Lu, Y., Jiang, S., Li, J., Guo, T., and Luo, C. (2015). Heterogeneity of the Lower Silurian Longmaxi marine Shale in the Southeast Sichuan Basin of China. Mar. Pet. Geology. 65, 232-246. doi:10.1016/j.marpetgeo.2015.04.003

Chen, X., Chen, L., Guo, X. S., and Wang, C. (2019). Geochemical Characteristics of Shale Gas in the Silurian Longmaxi Formation, Jiaoshiba Area, Southeast Sichuan Basin, China. Energy \& Fuel 33 (9), 8045-8054. doi:10.1021/acs. energyfuels. $9 \mathrm{~b} 03510$

Clarkson, C. R., Solano, N., Bustin, R. M., Bustin, A. M. M., Chalmers, G. R. L., He, L., et al. (2013). Pore Structure Characterization of North American Shale Gas Reservoirs Using USANS/SANS, Gas Adsorption, and Mercury Intrusion. Fuel 103, 606-616. doi:10.1016/j.fuel.2012.06.119

Cui, J. W., Zhu, R. K., Wu, S. T., and Bai, B. (2013). The Role of Pyrite in Shale Organic Matter Enrichment, Hydrocarbon Generation and Expulsion and Shale Oil Accumulation. Geol. Rev. 59 (1), 783-784.

Curtis, M. E., Sondergeld, C. H., Ambrose, R. J., and Rai, C. S. (2012). Microstructural investigation of gas shales in two and three dimensions using nanometer-scale resolution imaging. Bulletin 96 (4), 665-677. doi:10. 1306/08151110188

Duan, D. D., Zhang, D. N., Ma, X. X., Yang, Y., Ran, Y., and Mao, J. D. (2016). Chemical and Structural Characterization of Thermally Simulated Kerogen and its Relationship with Microporosity. Mar. Pet. Geology. 89, 4-13. doi:10.1016/j. marpetgeo.2016.12.016

Gao, Y., Cai, X., Zhang, P., He, G., Gao, Q., and Wan, J. (2019). Pore Characteristics and Evolution of Wufeng-Longmaxi Fms Shale Gas Reservoirs in the basinmargin Transition Zone of SE Chongqing. Nat. Gas Industry B 6 (4), 323-332. doi:10.1016/j.ngib.2018.12.002

Guo, T. (2015). The Fuling Shale Gas Field - A Highly Productive Silurian Gas Shale with High thermal Maturity and Complex Evolution History, southeastern Sichuan Basin, China. Interpretation 3 (2), SJ25-SJ34. doi:10. 1190/int-2014-0148.1

Guo, X. S., Li, Y. P., Liu, R. B., and Wang, Q. B. (2014). Characteristics and Controlling Factors of Micro-pore Structures of Longmaxi Shale Play in the Jiaoshiba Area, Sichuan Basin. Nat. Gas Industry 34 (6), 9-16. doi:10.3787/j. issn.1000-0976.2014.06.002

Hao, F., Zou, H., and Lu, Y. (2013). Mechanisms of Shale Gas Storage: Implications for Shale Gas Exploration in China. Bulletin 97 (8), 1325-1346. doi:10.1306/ 02141312091

Hu, Z. Q., Du, W., Peng, Y., and Zhao, J. (2015). Microscopic Pore Characteristics and the Source-Reservoir Relationship of Shale -A Case Study from the Wufeng and Longmaxi Formations in Southeast Sichuan Basin. Oil Gas Geology. 36 (6), 1001-1008. doi:10.11743/ogg20150615

Hunt, J. M., Lewan, M. D., and Hennt, J. C. (1991). Modeling Oil Generation Wth Time-Temperature index Graphs Based on the Arrhenius Equation. AAPG Bull 75 (4), 795-807. doi:10.1306/0c9b2853-1710-11d7-8645000102c1865d

IUPAC (International Union of Pure and Applied chemistry) (1994). Physical Chemistry Division Commission on Colloid and Surface Chemistry, Subcommittee on Characterization of Porous Solids. Recommendations for the Characterization of Porous Solids (Technical Report). Pure Appl. Chem. 66 (8), 1739-1758.

Jarvie, D. M., Hill, R. J., Ruble, T. E., and Pollastro, R. M. (2007). Unconventional Shale-Gas Systems: the Mississippian Barnett Shale of north-central Texas as One Model for Thermogenic Shale-Gas Assessment. Bulletin 91 (4), 475-499. doi:10.1306/12190606068

Jiang, Z. X., Tang, X. L., Li, Z., Huang, H. X., Yang, P. P., Yang, X., et al. (2016). The Whole-Aperture Pore Structure Characteristics and its Effect on Gas Content of the Longmaxi Formation Shale in the southeastern Sichuan basin. Earth Sci. Front. 23 (2), 126-134. doi:10.13745/j.esf.2016.02.013

Kuila, U., and Prasad, M. (2013). Specific Surface Area and Pore-Size Distribution in Clays and Shales. Geophys. Prospecting 61 (2), 341-362. doi:10.1111/13652478.12028
Liu, Z., Chen, D., Zhang, J., Lü, X., Wang, Z., Liao, W., et al. (2019). Pyrite Morphology as an Indicator of Paleoredox Conditions and Shale Gas Content of the Longmaxi and Wufeng Shales in the Middle Yangtze Area, South China. Minerals 9 (7), 428. doi:10.3390/min9070428

Liu, Z. Y., Zhang, J. C., Liu, Y., Yu, W. W., He, W., and Li, B. W. (2016). The Particle Size Characteristics of Pyrite in Western Hunan and Hubei Areas WufengLongmaxi Formation Shale. Sci. Techn. Eng. 16 (26), 34-41. doi:10.3969/j.issn. 1671-1815.2016.26.005

Loucks, R. G., Reed, R. M., Ruppel, S. C., and Jarvie, D. M. (2009). Morphology, Genesis, and Distribution of Nanometer-Scale Pores in Siliceous Mudstones of the Mississippian Barnett Shale. J. Sediment. Res. 79 (11 12), 848-861. doi:10. 2110/jsr.2009.092

Lu, J. M., Ruppel, S. C., and Rowe, H. D. (2015). Organic Matter Pores and Oil Generation in the Tuscaloosa Marine Shale. AAPG Bull 99 (2), 333-357. doi:10. 1306/08201414055

Ma, C. F., Dong, C. M., Luan, G. Q., Lin, C. Y., Liu, X. C., Duan, H. H., et al. (2017). Characteristics and Influencing Factors of Organic-Matter Pores in Paleogene Shale, Subei Basin. J. China Univ. Pet (Natural Sci. Edition) 41 (3), 1-13. CNKI: SUN:SYDX.0.2017-03-001

Mango, F. D. (1992). Transition Metal Catalysis in the Generation of Petroleum and Natural Gas. Gocehimica et Cosmochimica Acta 56 (01), 553-555. doi:10. 1016/0016-7037(92)90153-a

Raiswell, R., Buckley, F., Berner, R. A., and Anderson, T. F. (1988). Degree of Pyritization of Iron as a Paleoenvironmental Indicator of Bottom-Water Oxygenation. J. Sediment. Petrol. 58 (5), 812-819. doi:10.1306/212f8e722b24-11d7-8648000102c1865d

Roger, M. S., and Neal, R. O. (2011). Pore Types in the Barnett and Woodford Gas Shale: Contribution to Understanding Gas Storage and Migration Pathways in fine-grained Rocks. AAPG Bull 95 (12), 2017-2030. doi:10. 1306/03301110145

Ross, D. J. K., and Bustin, R. M. (2008b). Characterizing the Shale Gas Resource Potential of Devonian-Mississippian Strata in the Western Canada Sedimentary basin: Application of an Integrated Formation Evaluation. Bulletin 92 (1), 87-125. doi:10.1306/09040707048

Ross, D. J. K., and Bustin, R. M. (2008a). The Importance of Shale Composition and Pore Structure upon Gas Storage Potential of Shale Gas Reservoirs. Mar. Pet. Geology. 26 (6), 916-927. doi:10.1016/j.marpetgeo.2008.06.004

Ruppel, S. C., Reed, R. M., and Loucks, R. G. (2012). Spectrum of Pore Types and Networks in Mudrocks and a Descriptive Classification for Matrix-Related Mudrock Pores. AAPG Bull 96 (6), 1071-1098. doi:10.1306/08171111061

Shan, C. A., Zhang, T., Wei, Y., Zhang, Z., Wei, Y., and Zhang, Z. (2017). Shale Gas Reservoir Characteristics of Ordovician-Silurian Formations in the central Yangtze Area, China. Front. Earth Sci. 11 (1), 184-201. doi:10.1007/s11707016-0565-4

Shu, Y., Lu, Y., Chen, L., Wang, C., and Zhang, B. (2020). Factors Influencing Shale Gas Accumulation in the Lower Silurian Longmaxi Formation between the north and South Jiaoshiba Area, Southeast Sichuan Basin, China. Mar. Pet. Geology. 111, 905-917. doi:10.1016/j.marpetgeo.2019.06.029

Slatt, R. M., and O'Brien, N. R. (2011). Pore Types in the Barnett and Woodford Gas Shales: Contribution to Understanding Gas Storage and Migration Pathways in fine-grained Rocks. Bulletin 95 (12), 2017-2030. doi:10.1306/ 03301110145

Sun, B. S., and Guo, S. B. (2017). Characteristics of Microscopic Pores of Shale from Upper Sinian Doushantuo Formation in the Western of Hunan and Hubei, China and the Main Controlling Factors. J. Earch Sci. Environ. 39 (1), 114-125.

Tang, L., Song, Y., Li, Q. W., Pang, X. Q., Jiang, Z. X., Li, Z., et al. (2019). A Quantitative Evaluation of Shale Gas Content in Different Occurrence States of the Longmaxi Formation: A New Insight from Well JY-A in the Fuling Shale Gas Field, Sichuan Basin. Acta Geologica Sinica (English Edition) 93 (02), 400-419. doi:10.1111/1755-6724.13816

Tang, X., Zhang, J., Jin, Z., Xiong, J., Lin, L., Yu, Y., et al. (2015). Experimental Investigation of Thermal Maturation on Shale Reservoir Properties from Hydrous Pyrolysis of Chang 7 Shale, Ordos Basin. Mar. Pet. Geology. 64, 165-172. doi:10.1016/j.marpetgeo.2015.02.046

Tenger, B., Shen, B. J., Yu, L. J., Yu, L. J., Yang, Y. F., Zhang, W. T., et al. (2017). Mechanisms of Shale Gas Generation and Accumulation in the Ordovician Wufeng-Longmaxi Formation, Sichuan Basin, SW China. Pet Exploration Develop. 44 (1), 1000-0747. doi:10.1016/S1876-3804(17)30009-5 
Wang, Q., Lu, H., Shen, C., Liu, J., Peng, P. A., and Hsu, C. S. (2014a). Impact of Inorganically Bound Sulfur on Late Shale Gas Generation. Energy Fuels 28 (2), 785-793. doi:10.1021/ef401468w

Wang, Y. M., Dong, D. Z., Yang, H., He, L., Wang, S. Q., Huang, J. L., et al. (2014b). Quantitative Characterization of Reservoir Space in the Lower Silurian Longmaxi Shale, Southern Sichuan, China. Scientia Sinica (Terrae) 44 (6), 1348-1356. doi:10.1007/s11430-013-4645-y

Wang, Z. C., Zhao, W. Z., Zhang, L., and Wu, S. X. (2002). Tectonic Sequence and Natural Gas Exploration in the Sichuan Basin. Beijing: Geological Publishing House, 287p.

Wei, M., Xiong, Y., Zhang, L., Li, J., and Peng, P. a. (2016). The Effect of Sample Particle Size on the Determination of Pore Structure Parameters in Shales. Int. J. Coal Geology. 163, 177-185. doi:10.1016/j.coal.2016.07.013

Wilkin, R. T., Barnes, H. L., and Brantley, S. L. (1996). The Size Distribution of Framboidal Pyrite in Modern Sediments: An Indicator of Redox Conditions. Geochimica et Cosmochimica Acta 60 (20), 3897-3912. doi:10.1016/0016-7037(96)00209-8

Xu, Z. X., Han, S. M., and Wang, Q. C. (2015). Characteristics of Pyrite and its Hydrocarbon Significance of Shale Reservoir of Doushantuo Formation in Middle Yangtze Area. Lithologic Reservoirs 27 (02), 31-37. doi:10.3969/j.issn. 1673-8926.2015.02.006

Yu, B. S. (2013). Classification and Characterization of Gas Shale Pore System. Earth Sci. Front. 20 (4), 211-220.

Zargari, S., Canter, K. L., and Prasad, M. (2015). Porosity Evolution in Oil-Prone Source Rocks. Fuel 153, 110-117. doi:10.1016/j.fuel.2015.02.072

Zhang, H., Zhu, Y., Wang, Y., Kang, W., Chen, S., and Chen, S. B. (2016). Comparison of Organic Matter Occurrence and Organic Nanopore Structure within marine and Terrestrial Shale. J. Nat. Gas Sci. Eng. 32 (5), 356-363. doi:10.1016/j.jngse.2016.04.040

Zhao, D. F., Guo, Y. H., Zhu, Y. M., Geoff, W., Liu, J., Chong, X., et al. (2018). Micropore Characteristics and Geological Significance of Pyrite in Shale Rocks of Longmaxi Formation. Acta Sedimentlogica Sinica 36 (05), 864-876. doi:10. 14027/j.issn.1000-0550.2018.077

Zhao, S. X., Yang, Y. M., Zhang, J., Wang, L. S., Wang, X. Z., Luo, C., et al. (2016). Micro-layers Division and fine Reservoirs Contrast of Lower Silurian Longmaxi Formation Shale, Sichuan Basin, SW China. Nat. Gas Geosci. 27 (3), 470-487. CNKI:SUN:TDKX.0.2016-03-011
Zheng, X., Zhang, B., Sanei, H., Bao, H., Meng, Z., Wang, C., et al. (2019). Pore Structure Characteristics and its Effect on Shale Gas Adsorption and Desorption Behavior. Mar. Pet. Geology. 100, 165-178. doi:10.1016/j. marpetgeo.2018.10.045

Zou, C., Dong, D., Wang, Y., Li, X., Huang, J., Wang, S., et al. (2016). Shale Gas in China: Characteristics, Challenges and Prospects (II). Pet Exploration Develop. 43 (2), 182-196. doi:10.1016/s1876-3804(16)30022-2

Zou, C., Du, J., Xu, C., Wang, Z., Zhang, B., Wei, G., et al. (2014). Formation, Distribution, Resource Potential, and Discovery of Sinian-Cambrian Giant Gas Field, Sichuan Basin, SW China. Pet Exploration Develop. 41 (3), 306-325. doi:10.1016/s1876-3804(14)60036-7

Conflict of Interest: WC was employed by Sinopec. YJ and GW were employed by PetroChina.

The remaining authors declare that the research was conducted in the absence of any commercial or financial relationships that could be construed as a potential conflict of interest.

The reviewer YS declared a shared affiliation with one of the authors, CW, to the handling editor at time of review.

Publisher's Note: All claims expressed in this article are solely those of the authors and do not necessarily represent those of their affiliated organizations, or those of the publisher, the editors, and the reviewers. Any product that may be evaluated in this article, or claim that may be made by its manufacturer, is not guaranteed or endorsed by the publisher.

Copyright (C) 2022 Chen, Chen, Tan, Wang, Ji, Xiong and Wang. This is an openaccess article distributed under the terms of the Creative Commons Attribution License (CC BY). The use, distribution or reproduction in other forums is permitted, provided the original author(s) and the copyright owner(s) are credited and that the original publication in this journal is cited, in accordance with accepted academic practice. No use, distribution or reproduction is permitted which does not comply with these terms. 